\title{
Prototype of Voice Commanded University Executive Business Intelligence Assistant (BELA)
}

\author{
Mohamad Irwan Afandi ${ }^{1}$, Eka Dyar Wahyuni ${ }^{2}$ \\ Information Systems Department \\ Universitas Pembangunan Nasional "Veteran" Jawa Timur \\ Surabaya, Indonesia \\ ${ }^{1}$ mohamadafandi.si@upnjatim.ac.id, 2ekawahyuni.si@upnjatim.ac.id
}

\begin{abstract}
Higher education institutions have already started implementing business intelligence application in order to support university executives to make better decisions. Normally, an application is operated using a mouse, keyboard, or touch-screen device which in some cases is not suitable for the users. The recent researches and developments in natural language processing open up opportunities for implementation in in the field of information systems. This paper presents a prototype of a voice commanded executive business intelligence assistant which gives the users the comfort to request for information to be displayed on the screen using their voice.
\end{abstract}

Keywords-assistant; business intelligence; executive; voice command;

\section{INTRODUCTION}

The continuous Information and Communication Technology (ICT) development have opened up opportunities for further advancements in the systems and applications development for both organization and personal use, either as answers for users' needs (market pull) or innovations (technology push).

One of the revolutionary development of ICT is the fundamental and applied research in natural language processing especially the transformation of speech into text and text into speech at which the precision is only getting more accurate and the language support is also growing time by time. Google Assistant and Apple Siri are notably among the pioneers and leaders in the area of voice assistant application running on mobile device.

Science-fiction movie "Iron Man" is perhaps the best example of how human (Tony Stark) communicates interactively with a computer system named "Jarvis" (Just Another Rather Very Intelligent Systems) which acts as an intelligent assistantfor Tony Stark equipped with the capability of executing movement commands, monitoring and informing health status and even analyzing and giving suggestion.

There have been numerous researches in the use of voice or speech to command a system to complete tasks such as controlling robot [1][2], playing music [3], opening/closing doors and windows [4], and others [5][6][7][8].
The recent work by [9] presents fifteen chatbot agents developed using Dialogflow which are installed in the London Olympic Park and capable of communicating with parkgoers regarding the park facilities.

Meanwhile, in the area of information systems, business organizations has implemented data warehouse [10-12] combined with business intelligence [13-17] intended to provide executives and decision makers the power to quickly view, analyze and interpret aggregate data and information in various forms (charts, table, etc) and various dimensions. These abilities provided by the system have proven key to better decision making.

On the other hand, higher education institutions, due to their not-for-profit oriented mission, even though a little bit late compared to their business organizations but have already started to realize the need for such system and launched a business intelligence project as an effort to deliver better operational services and high-quality education.

Generally, the business intelligence applications and other information systems are operated on using mice, keyboards, touch-screens or interactive screen/boards. This research was intended to extend the way of operating a business intelligence system by developing a prototype of voice-commanded computer assistant which would enable the user to request for data and information using voice in addition to the existing ways.

\section{METHODOLOGY}

The overall steps used in this research is presented in Fig. 1. This research started with the data collection and analysis where for this study a subset of academic data and financial data are used. Academic data collected are students' grades on all courses and all semesters from 2014-2017 while the financial data gathered are proposals for disbursement.

The next step was data warehouse design and ETL processing. This step produces star schemas for both academic and financial based on the availability of data collected and analyzed during the first step.

For academic business processes, the star schema captures every row of the score students receive for each course they 
have taken in regular semesters from 2014-2017. The academic fact table contains totalScore, totalScoreWeight, midExamScore, and finalExamScore as measures while the dimension tables used are students, times, and faculties.

The star schema for financial business process describes every row of the total amount for each disbursement proposal submitted by any given unit in the university. It is worth noted that every unit is permitted to submit the proposal more than once a month as long as the total amount of all proposals in one month does not exceed a certain limit set by the university. The financial fact table contains one measure which is amount while the dimension tables are unit and times.

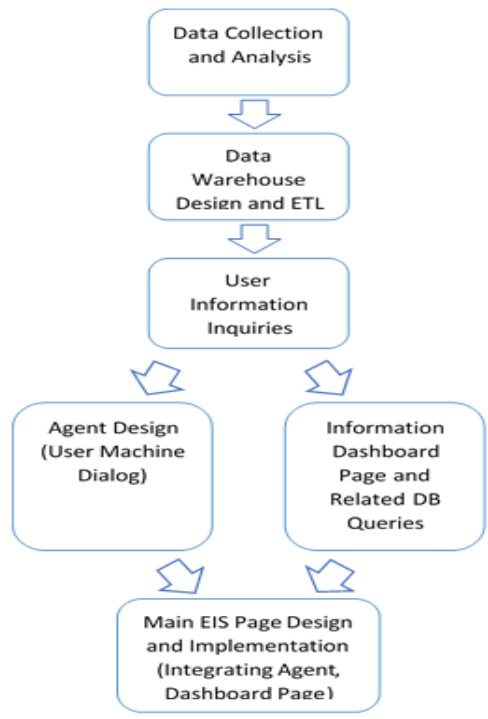

Fig. 1. Research Methodology

Both data warehouse star schemas were then physically implemented and followed by ETL process design using Pentaho Data Integration. This particular step was ended with the execution of the ETL process which extracts data from corresponding source tables in operational databases, transforms the data and load them into the data warehouse.

Based on the star schema, executive's possible inquiries for academic and financial information were identified and formatted in the form of a dialog scenario. Part of dialog scenarios written in English (translated from original scripts written in Indonesian) between the user and computer assistant is shown in Table $\mathrm{I}$.

Two parallel steps which are agent design and information dashboard design were then executed. The agent design was done using Dialogflow as shown in Fig. 2. The dashboard page was designed using Chart.js, PHP and Javascript. The last step was designing the main page and integrating it with the Dialogflow agent and corresponding dashboard pages as well as with the ResponsiveVoice JS.
TABLE I. PARTIAL USER-ASSISTANT Dialog SCENARIOS

\begin{tabular}{|c|c|c|c|c|}
\hline \# & Topic & $\begin{array}{c}\text { User } \\
\text { (Executive) } \\
\text { DialogScript }\end{array}$ & $\begin{array}{c}\text { Computer } \\
\text { Assistant Dialog } \\
\text { Script }\end{array}$ & Remarks \\
\hline \multirow[t]{4}{*}{1} & Greetings & $\begin{array}{c}\text { Good } \\
\text { [Morning } \\
\text { |Afternoon } \\
\text { |Evening], } \\
\text { BELA }\end{array}$ & $\begin{array}{l}\text { Good [Morning } \\
\text { |Afternoon } \\
\text { |Evening],Sir }\end{array}$ & $\begin{array}{l}\text { Computer } \\
\text { Assistant } \\
\text { shall correct } \\
\text { user's } \\
\text { wrongly } \\
\text { said time } \\
\text { greeting } \\
\text { (time } \\
\text { awareness) }\end{array}$ \\
\hline & & $\begin{array}{l}\text { How are you } \\
\text { today? }\end{array}$ & $\begin{array}{l}\text { I am feeling good, } \\
\text { Sir. Hopefully, I } \\
\text { will serve you better } \\
\text { today, Sir. And how } \\
\text { are you, Sir }\end{array}$ & \\
\hline & & $\begin{array}{l}\text { Alhamdulillah } \\
\text {, I am doing } \\
\text { good. }\end{array}$ & $\begin{array}{l}\text { Thank God, Sir. Is } \\
\text { there anything I can } \\
\text { do for you, Sir }\end{array}$ & \\
\hline & & $(\ldots)$ & $(\ldots)$ & \\
\hline \multirow[t]{3}{*}{$\overline{2}$} & $\begin{array}{l}\text { Request for } \\
\text { News }\end{array}$ & $\begin{array}{l}\text { What } \\
\text { today's } \\
\text { education } \\
\text { news? }\end{array}$ & $\begin{array}{c}\text { External or internal } \\
\text { news, Sir? }\end{array}$ & \\
\hline & & $\begin{array}{l}\text { External, } \\
\text { please }\end{array}$ & $\begin{array}{l}\text { These are the list, } \\
\text { Sir. [Show the top } \\
\text { three list and read } \\
\text { the news title]. } \\
\text { Which news you } \\
\text { like to read, Sir, the } \\
1^{\text {st }}, 2^{\text {nd }} \text { or } 3^{\text {rd }} \text { ? }\end{array}$ & \\
\hline & & $(\ldots)$ & $(\ldots)$ & \\
\hline \multirow[t]{4}{*}{3} & $\begin{array}{l}\text { Request for } \\
\text { Executive } \\
\text { Information } \\
\text { on } \\
\text { Academic } \\
\text { Performance }\end{array}$ & $\begin{array}{l}\text { Show } \\
\text { academic } \\
\text { performance } \\
\text { chart }\end{array}$ & $\begin{array}{l}\text { Display the bar } \\
\text { chart of average } \\
\text { GPA per faculty in } \\
\text { the last } 4 \text { years }\end{array}$ & \multirow{3}{*}{$\begin{array}{l}\text { Follow-up } \\
\text { event. The } \\
\text { second and } \\
\text { later series } \\
\text { of inquiries } \\
\text { are related } \\
\text { and based } \\
\text { on the } \\
\text { initial } \\
\text { inquiry. } \\
\text { The } \\
\text { computer } \\
\text { agent will } \\
\text { use } \\
\text { previous } \\
\text { information } \\
\text { and } \\
\text { combine it } \\
\text { with } \\
\text { following } \\
\text { information } \\
\text { to correctly } \\
\text { predict the } \\
\text { intention } \\
\text { and } \\
\text { information } \\
\text { needed by } \\
\text { the user. }\end{array}$} \\
\hline & & $\begin{array}{l}\text { Drill-down on } \\
\text { Faculty of } \\
\text { [Agriculture } \\
\text { |Economy } \\
\text { Engineering } \\
\text { |etc] }\end{array}$ & $\begin{array}{l}\text { Show the bar chart } \\
\text { of average GPA } \\
\text { the last } 4 \text { years per } \\
\text { department in the } \\
\text { same faculty }\end{array}$ & \\
\hline & & $\begin{array}{l}\text { Drill-down on } \\
\text { Department } \\
\text { [Chemical } \\
\text { Engineering| } \\
\text { Industrial } \\
\text { Engineering| } \\
\text { |etc] }\end{array}$ & $\begin{array}{l}\text { Show the bar chart } \\
\text { of average GPA per } \\
\text { student intake year } \\
\text { in the last } 4 \text { years in } \\
\text { the department } \\
\text { selected }\end{array}$ & \\
\hline & & $(\ldots)$ & $(\ldots)$ & \\
\hline 4 & $\begin{array}{l}\text { Request for } \\
\text { Executive } \\
\text { Information } \\
\text { on Financial } \\
\text { Performance }\end{array}$ & $\begin{array}{l}\text { Show me } \\
\text { financial } \\
\text { performance } \\
\text { chart in } \\
\text { [Januaryl }\end{array}$ & $\begin{array}{l}\text { Display the bar } \\
\text { chart } \\
\text { disbursement } \\
\text { proposal of all first } \\
\text { level group of }\end{array}$ & $\begin{array}{l}\text { Follow-up } \\
\text { event. The } \\
\text { second and } \\
\text { later series } \\
\text { of inquiries }\end{array}$ \\
\hline
\end{tabular}




\begin{tabular}{|c|c|c|c|c|}
\hline \# & Topic & $\begin{array}{c}\text { User } \\
\text { (Executive) } \\
\text { DialogScript }\end{array}$ & $\begin{array}{c}\text { Computer } \\
\text { Assistant Dialog } \\
\text { Script }\end{array}$ & Remarks \\
\hline & & $\begin{array}{l}\text { February| } \\
\text { March| } \\
\text { December] }\end{array}$ & $\begin{array}{l}\text { university } \\
\text { organization in the } \\
\text { month selected }\end{array}$ & \multirow{3}{*}{$\begin{array}{l}\text { are related } \\
\text { and based } \\
\text { on the } \\
\text { initial } \\
\text { inquiry. } \\
\text { The } \\
\text { computer } \\
\text { agent will } \\
\text { use } \\
\text { previous } \\
\text { information } \\
\text { and } \\
\text { combine it } \\
\text { with } \\
\text { following } \\
\text { information } \\
\text { to correctly } \\
\text { predict the } \\
\text { intention } \\
\text { and } \\
\text { information } \\
\text { needed by } \\
\text { the user. }\end{array}$} \\
\hline & & $\begin{array}{l}\text { Drill-down on } \\
\text { the first level } \\
\text { group } \\
\text { [Faculty|UPT| } \\
\text { Lembaga| } \\
\text { Biro] }\end{array}$ & $\begin{array}{l}\text { Display the bar } \\
\text { chart breakdown of } \\
\text { disbursement } \\
\text { proposal of the } \\
\text { second level group } \\
\text { of university } \\
\text { organization under } \\
\text { the first level group } \\
\text { selected in the } \\
\text { month selected } \\
\text { previously }\end{array}$ & \\
\hline & & $\begin{array}{l}\text { Drill-down on } \\
\text { the name of } \\
\text { the second } \\
\text { level group [ }\end{array}$ & $\begin{array}{l}\text { Display the bar } \\
\text { chart breakdown of } \\
\text { disbursement } \\
\text { proposal of the unit } \\
\text { under the second } \\
\text { level group selected } \\
\text { in the month } \\
\text { selected previously }\end{array}$ & \\
\hline & & $(\ldots)$ & $(\ldots)$ & \\
\hline
\end{tabular}

Fig. 2 shows the block diagram of the business intelligent assistant (BELA). It presents the high-level interacting components of the systems that can be grouped into three separate sub-systems which are Text-to-Speech, Local Web Application, and NLP Engine.

After searching and careful examinations, ResponsiveVoice JS was used since it was the best in term of simplicity, accuracy, and voice quality compared to other similar applications available on the Internet. Moreover, its license policy was suitable for a non-profit organization such as a university.

Dialogflow on the other hand was selected as a Natural Language Processing (NLP) Engine for the systems since it is powered by Google Machine Learning (ML) technology which offers power, simplicity, and security at the same time for agent/assistant design and integration with local web applications.

The local web application consists of four components which are the main web page, dashboard pages, data warehouse, and webhook. The main page serves as the primary and only interface the user can interact with the system. The main page prompts the user to start sending voice message or command to the system by pressing a voice record button. The recorded voice is then sent to the Dialogflow to be recognized, analyzed and interpreted. All voice input will be printed back to the User-Assistant Dialog section along with the textual reply depending on the result of the voice recognition and the interpretation. If the voice recorded was interpreted as a greeting, the system will return a greeting textual message both to the input/output (console) section and to the ResponsiveVoice JS which will subsequently return the corresponding voice to the speaker device at almost the same time.

If the voice recorded was interpreted as a command, the system will map it to the correct Intents defined in the Dialogflow which will then call the corresponding dashboard page, execute the database queries, and return the results in the form of chart to the graphical output section of the main page along with text message into to input/output (console) as well as to the ResponsiveVoice JS and finally send the corresponding voice to the speaker timely.

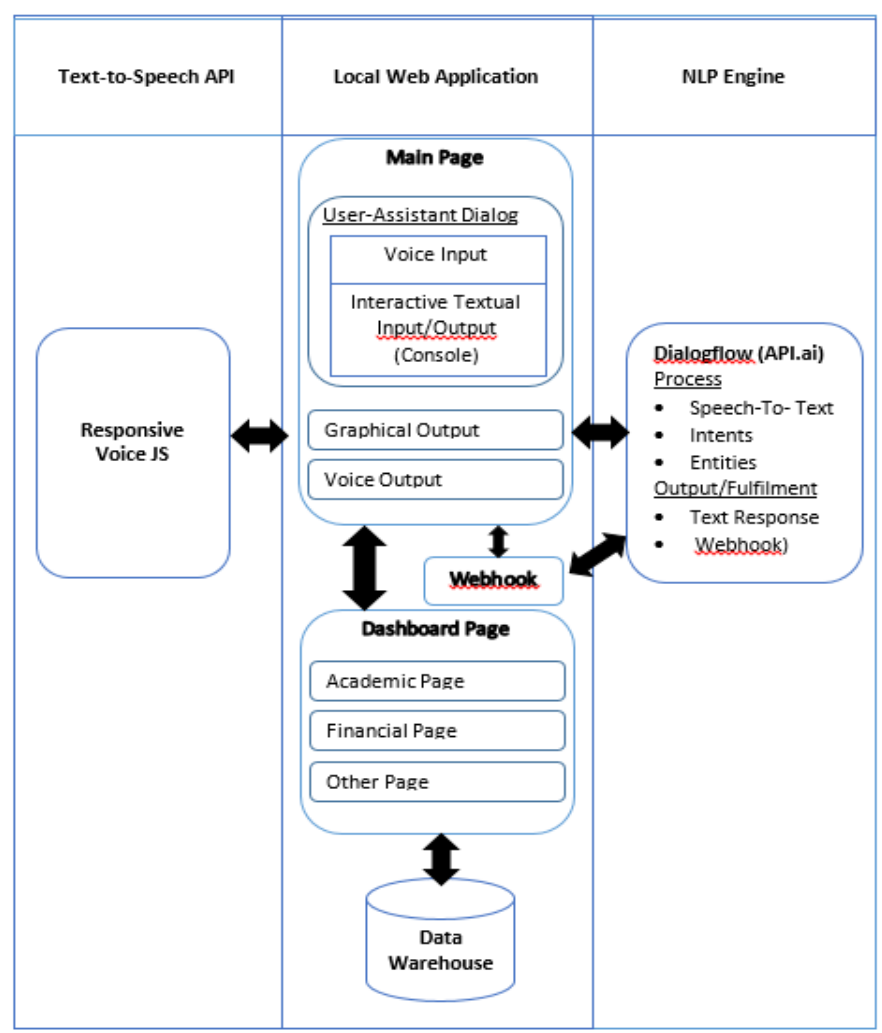

Fig. 2. Block diagram of Business Intelligence Assistant (BELA)

Fig. 3 presents the all the intents designed in Dialogflow, various training phrases to recognize the user voice command for financial related Intents "laporan keuangan", the action and parameters of Intents "laporan keuangan" and the Entities of Intents "laporan keuangan".

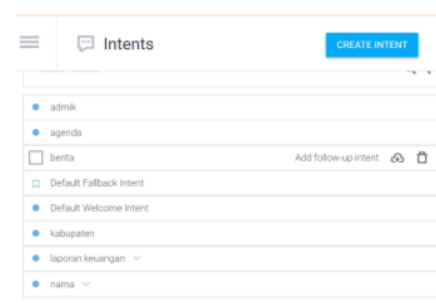

(a)

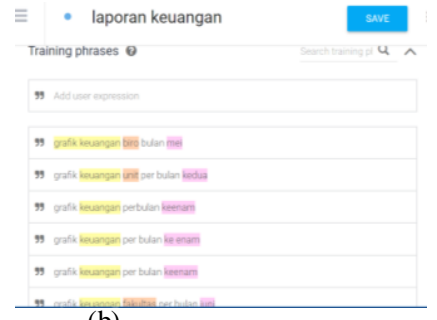

(b) 


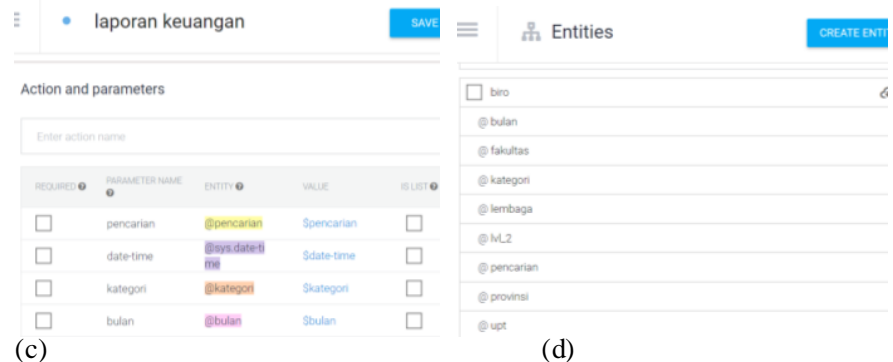

(d)

Fig. 3. Dialogflow design of (a) All Intents, (b) Training phrases, (c) Action and Parameters of, and (d) Entities.

\section{RESULT AND DISCUSSION}

The system that has been developed were then tested and compared against the scenario prepared. A number of testing results are presented in the following series of figures.

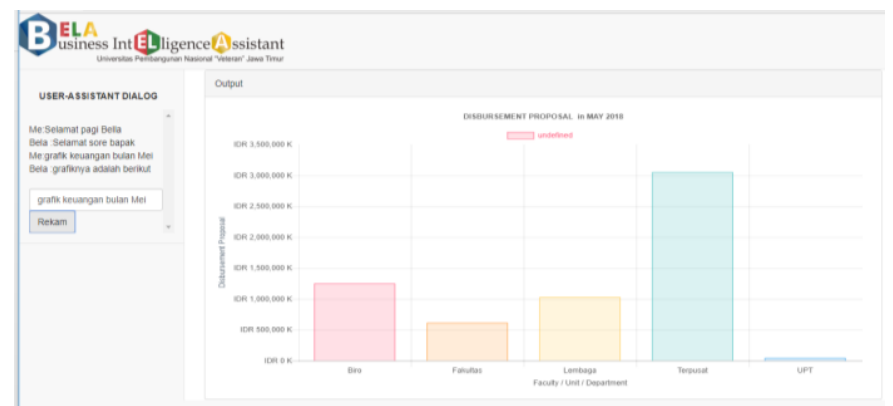

Fig. 4. Request for first level group financial performance chart

In Fig. 4, the User-Assistant Dialog section on left side of the page shows the history of interactive communication between the user and the system while the chart on the right displays correctly the disbursement proposal comparison between parties of first level group in May as commanded by the user using the sentence "grafik keuangan bulan mei" which means "show financial chart for the month of May".

Both Fig. 5 and Fig. 6 exhibits the concept of "Drill-Down" where one would be able to drill for detailed information generally by clicking on the particular area of the chart or other interface provided on the system. Only that in BELA, users would only need to speak the data label name he or she is intended to further explore. Fig. 4 displays disbursement proposals of all faculties and Fig. 5 displays an even detailed disbursement proposals under the Faculty of Economy.

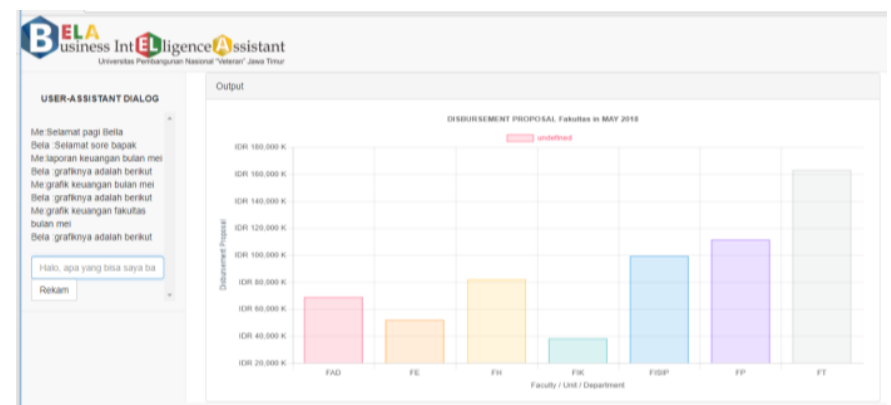

Fig. 5. Drill-down request for all faculties financial performance chart

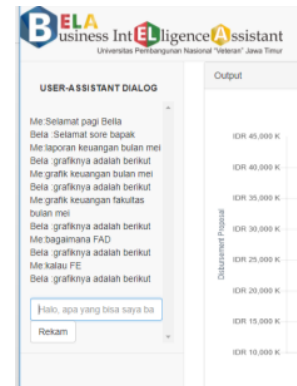

Fig. 6. Drill-down request for economic faculty financial performance chart

Fig. 7 demonstrates the execution of user's call for academic performance chart and the system responds appropriately by displaying a comparis on of students GPA in their respective faculties in the last 4 years.

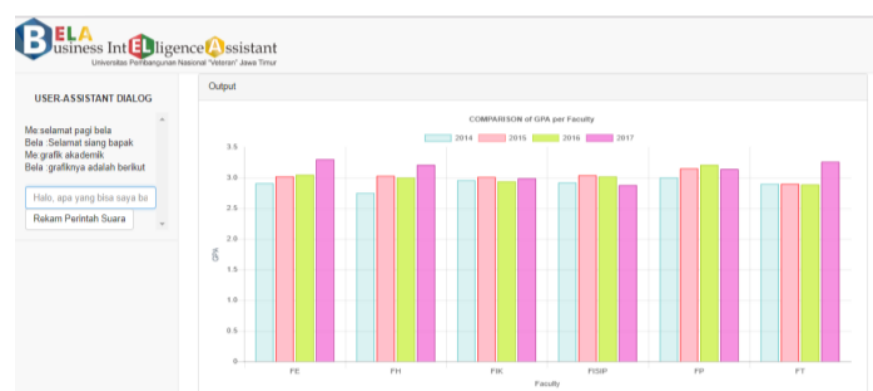

Fig. 7. Block Diagram of Business Intelligence Assistant (BELA)

The perfect fulfillment to a drill-down inquiry on the faculty of engineering (FT) and further on the department of civil engineering (TS) is depicted in Fig. 8 and Fig. 9 respectively.

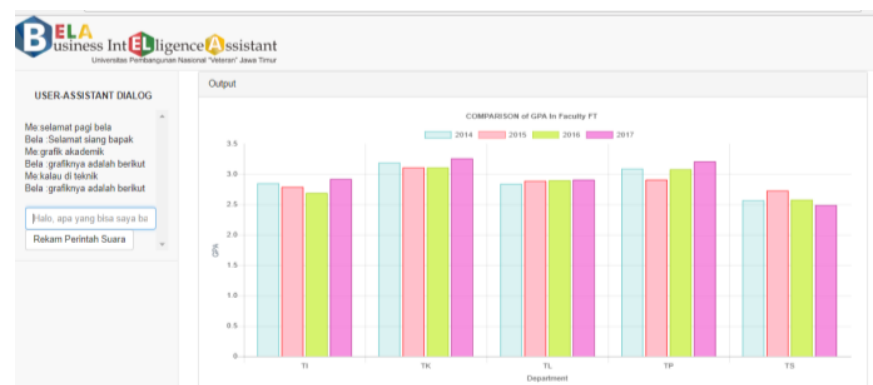

Fig. 8. Block Diagram of Business Intelligence Assistant (BELA)

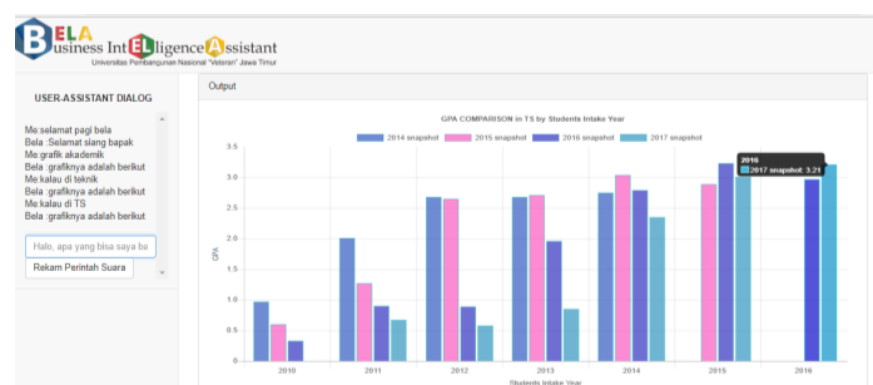

Fig. 9. Block Diagram of Business Intelligence Assistant (BELA) 


\section{CONCLUSION}

The proposed prototype of voice commanded university executive business intelligent assistant (BELA) has been developed and proven to be effective in fulfilling user inquiries efficiently. Executives who for some reasons are unable or unwilling to use mouse or keyboard to operate a system can now use their voices as an alternative. Even though the potentials for future further research and development are still wide open, the current version of BELA has already demonstrated to be useful, easy, and flexible.

\section{ACKNOWLEDGMENT}

Authors would like to thank the research and community service institution (LPPM) of Universitas Pembangunan Nasional "Veteran" Jawa Timur for fully funding this research project. Authors also thank the Information \& Communication Technology Unit (UPT TIK) of Universitas Pembangunan Nasional "Veteran" Jawa Timur for providing access to university academic and financial databases.

\section{REFERENCES}

[1] S. Patil, A. Abhigna, "Voice Controlled Robot Using Labview," 2018 Int. Conf. on Des. Innov. for 3Cs Comput. Commun. Control. (ICDI3C), pp. 80-83, 2018.

[2] S. Pleshkova, and Z. Zahariev, "Development of system model for audio visual control of mobile robots with voice and gest ure commands", 2017 40th Int. Springs. Seminar on Electron. Technol. (ISSE), pp. 1-4, 2017.

[3] O.F. Bertol and P. Nohama, "MP3 Player Powered by Voice Commands," 2015 Pan Am. Health.C. Exch.(PAHCE), pp. 1-1, 2015.

[4] R.L.H. Pakpahan, D.W. Sudiharto and A.G.P. Sat wiko, "The prototype of aut omated doors and windows by using voice commands," 2016 Int . Seminar on App. for Technol. of Inf. and Commun. (ISemantic), pp. 323-326, 2016.

[5] M. Fezari, M.S. Boumaza, and A. Aldahoud, "Voice command system based on pipelining classifiers GMM-HMM", 2012 Int. Conf. on Inf. Technol. and e-Serv, pp. 1-6, 2012.
[6] H. Hickersberger \& Zagler, “ A voice command system for AUTONOMY using a novel speech alignment algorithm, W.L. Int J Speech. Technol., vol. 16, pp 461, 2013.

[7] T. Kuremoto, T. Yamane, L.Feng, K. Kobayashi, and M. Obayashi, A "Human-Machine Interaction System: A Voice Command Learning System Using PL-G-SOM", 2011 Int. Conf. on Manag. and Serv. Sci., pp. 1-4, 2011.

[8] E. Kurniawati, L. Celetto, N. Capovilla and S. George, Personalized voice command systems in multi modal user interface, 2012 IEEE Int. Conf. on Emerg. Signal Proc. App., pp. 45-47, 2012.

[9] R. Milton, D. Hay, S. Gray, B. Buyuklieva and A. Hudson-Smith, "Smart IoT and Soft AI," Living in the Internet of Things: Cybersecur. of the IoT - 2018, London, pp. 1-6, 2018.

[10] Y. Bassil, “A Data Warehouse Design for A Typical University Information System", J. of Comp. Sci. \& Res. (JCSCR) - ISSN 2227 328X, Vol. 1, No. 6, Pages. 12-17, 2012.

[11] N. Dedić, and C. Stanier, "An Evaluation of the Challenges of Multilingualism in Data Warehouse Development" in 18th Int. Conf. on Enterp. Inf. Syst. - ICEIS 2016, p. 196, ,2016.

[12] Patil, S. Preeti, Srikantha Rao; Suryakant B. Patil . "Optimization of Data Warehousing System: Simplification in Reporting and Analysis". IJCA Proc. on Int. Conf. and workshop on Emerg. Trends in Technol. (ICWET). Found. of Comput. Sci.. vol. 9 (6): 33-37, 2011.

[13] Javier, Kevin, "HigherEducation Meets Business Intelligence", Student Theses, Papers and Project. (Comput. Sci.), 2017. Download from https://digitalcommons.wou.edu/computerscience_studentpubs/1

[14] N.A.H.M. Rodzi, M.S. Othman and L.M. Yusuf, "Significance of data integration and ETL in business intelligence framework for higher education," 2015 Int. Conf. on Sci. in Inf. Technol. (ICSITech), pp. 181$186,2015$.

[15] T. Nobre, A. Trigo and P. Sanches, "SBIAES - Business intelligence system for analysis of access to higher education: The case of the Polytechnic Institute of Coimbra," 2014 9th Iberian Conf. on Inf. Syst. and Technol. (CISTI), pp. 1-6, 2014.

[16] M.B. Piedade and M.Y. Santos, "Business intelligence in higher education: Enhancing the teaching-learning process with a SRM system," 5th Iberian Conf. on Inf. Syst. and Technol., pp. 1-5, 2010.

[17] D. Apraxine and E. Stylianou, "Business intelligence in a higher educational institution: The case of University of Nicosia," 2017 IEEE Glob. Eng. Edu. Conf. (EDUCON), pp. 1735-1746 2017. 